\title{
ANTI-INFLAMMATORY DRUG-LOADED BIOPOLYMERIC SPONGIOUS MATRICES WITH THERAPEUTIC PERSPECTIVES IN BURNS TREATMENT
}

\author{
DENISA IOANA UDEANU ${ }^{1}$, MĂDĂLINA GEORGIANA ALBU KAYA ${ }^{2}$, MIHAELA VIOLETA \\ GHICA $^{3 *}$, ȘTEFANIA MARIN ${ }^{2,4}$, MARIA MINODORA MARIN ${ }^{2,5}$, DURMUȘ ALPASLAN \\ KAYA $^{6}$, LĂCRĂMIOARA POPA ${ }^{3}$, CRISTINA DINU-PIRVU ${ }^{3}$ \\ 1 "Carol Davila” University of Medicine and Pharmacy, Faculty of Pharmacy, Department of Clinical Laboratory and Food \\ Safety, 6 Traian Vuia Street, 020956, Bucharest, Romania \\ ${ }^{2}$ The National Research \& Development Institute for Textiles and Leather, Division of Leather and Footwear Research Institute, \\ Department of Collagen Research, 93 Ion Minulescu Street, 031215, Bucharest, Romania \\ 3 "Carol Davila" University of Medicine and Pharmacy, Faculty of Pharmacy, Department of Physical and Colloidal Chemistry, \\ 6 Traian Vuia Street, 020956, Bucharest, Romania \\ ${ }^{4}$ University Politehnica of Bucharest, Faculty of Applied Sciences, 313 Splaiul Independentei Street, 060042, Bucharest, Romania \\ ${ }^{5}$ University Politehnica of Bucharest, Faculty of Applied Chemistry and Material Science, 1-7 Gheorghe Polizu Street, 011061, \\ Bucharest, Romania \\ "'Mustafa Kemal” University, Faculty of Agriculture, Department of Field Crops, Antakya-Hatay, 31030, Turkey
}

*corresponding author: mihaelaghica@yahoo.com

\begin{abstract}
The most important goals of burns treatment suppose a fast skin regeneration to promote healing, the initial pain reduction and minimal scars forming. The development of new biopolymers-based wound dressings to ensure a proper healing process is nowadays a major challenge considering the incidence and consequences of burns. Our previously designed antiinflammatory drug-loaded biopolymeric spongious matrices were initially tested by in vitro analysis and revealed proper morphological structure, swelling ability, degradation profiles and drug release patterns, indicating their potential use for burns treatment. Thus, the study aims to evaluate some collagen-sodium carboxymethylcellulose spongious matrices with or without mefenamic acid as non-steroidal anti-inflammatory drug in experimentally induced burns on Wistar rats, a frequently used animal model for the assessment of wounds healing. The treatment with the designed sponges promoted the wound healing compared to the classical treated control group. The sponges with mefenamic acid accelerated the healing process with a faster epithelial regeneration and a minimal scarring in comparison with the formulations containing no antiinflammatory drug.
\end{abstract}

\section{Rezumat}

Cele mai importante ținte în terapia arsurilor presupun regenerarea rapidă a pielii cu favorizarea vindecării, reducerea durerii inițiale și formarea unor cicatrici minimale. Dezvoltarea de noi pansamente pe bază de biopolimeri pentru a asigura un proces de vindecare adecvat este o provocare actuală având în vedere incidența și consecințele arsurilor. Matrici spongioase biopolimerice cu medicamente antiinflamatoare realizate anterior au fost inițial testate prin analize in vitro demonstrând structură morfologică, capacitate de gonflare, profile de degradare și de cedare adecvate, indicate pentru utilizarea acestora în tratamentul arsurilor. Astfel, studiul își propune să determine efectul unor matrici spongioase pe bază de colagen și carboximetilceluloză sodică cu sau fără conținut de acid mefenamic ca medicament antiinflamator asupra arsurilor induse experimental la șobolanii Wistar, un model animal folosit frecvent în evaluarea procesului de vindecare a rănilor. Tratamentul cu matricile spongioase proiectate a favorizat procesul de vindecare comparativ cu lotul martor care a primit tratamentul clasic. Matricile spongioase ce conțin acid mefenamic au accelerat procesul de vindecare cu o regenerare mai rapidă și cu formarea unor cicatrici minime, comparativ cu formulările care nu conțin agent antiinflamator.

Keywords: burn healing, biopolymeric spongious matrices, anti-inflammatory drug

\section{Introduction}

Burns with different severity degrees affect a significant part of population $[6,24,36]$ and are associated with a long healing period, involving high treatment costs for patient's recovery and reintegration [23].
The healing of this type of injury consists of four sequential, overlapping and integrated events: homeostasis, inflammation, proliferation and remodelling [24, 35, 36, 40].

The most important goals of burns treatment are supposing a fast skin regeneration to promote healing, reducing the initial pain and preventing the formation 
of thick layer scars [36]. Classic burn therapy is insufficient in achieving these goals. The development of new biopolymers-based wound dressings for promoting a proper healing process is nowadays a target and a major challenge considering the incidence and secondary effects of burns [24].

Among these biopolymers, an increased interest is given to collagen, a good candidate in the wound management due to its unique biological characteristics: excellent biocompatibility, haemostasis, biodegradability, low antigenicity, promoting cell attachment and proliferation [8, 22, 25, 38, 39].

Collagen can be used in various forms [36], the spongious matrices or sponges obtained by lyophilisation of collagen solutions/gels being widely used as wound dressings [20] due to their proven capacity in different aetiology lesions healing $[11,13,14,16]$.

To overcome the drawbacks related to the poor mechanical strength and low resistance to enzymatic biodegradation of the un-denatured collagen, either crosslinking agents such as glutaraldehyde $[11,19,31]$ or co-blending with other biopolymers for stabilizing the spongious matrices are used [31, 41].

Sodium carboxymethyl cellulose ( $\mathrm{NaCMC}$ ) is a semisynthetic non-ionic cellulose ether derivative with many applications in pharmaceutical and cosmetic formulations due its intrinsic properties: biocompatibility, biodegradability, bioadhesivity, non-toxicity, high swelling degree, gelation ability, low manufacturing cost and high drug loading capacity $[4,5,7,12,28$, $29,32]$. Moreover, NaCMC used as wound dressings showed a significant potential in improving lesion healing and maintaining a moist environment $[7,29$, $32,37]$.

To improve the burn healing process, the biopolymerbased wound dressings are loaded with non-steroidal anti-inflammatory drugs (NSAIDs), avoiding in this way further inappropriate cicatrizing process determined by the elevated post-traumatic inflammation [11,27]. Topical NSAIDs, used to inhibit the associated pain and the enhancement of inflammation occurred in the first hours of a burned wound, represent a reliable alternative to the systemic administration that does not reach the affected tissue in an effective and sufficient drug concentration, has a high toxicity at gastro-duodenal level and secondary renal and hepatic effects $[3,9,10,21]$.

Mefenamic acid (MA), a non-steroidal anti-inflammatory drug (2-[(2,3-dimethylphenyl)amino]benzoic acid), belongs to Biopharmaceutics Classification System class II (low solubility and high permeability) [26, 34]. $\mathrm{MA}$, available on market in different forms as tablets, capsules, suspensions, is used to reduce pain and the first phase of post-traumatic inflammation by inhibition of cyclooxygenase- 2 and prostaglandin synthesis [2, 33, 34], proving also its efficiency in various topical designed formulations $[17,18]$. Due to its short elimination half-life (2 hours) [34] and side effects specific to the NSAIDs, using the MA for the topical route of administration is a viable option. Initial screening for a potential therapeutic use in burn healing of some collagen-NaCMC spongious matrices with or without mefenamic acid was previously determined by in vitro tests [30]. Thus, the biopolymeric spongious matrices were investigated by optical microscopy, FT-IR spectroscopy, water absorption, enzymatic degradation and drug release kinetics analysis. FT-IR analysis indicates that collagen macromolecule preserves the triple helix structure, while optical images indicate a structure specific to collagen with interconnected pores. The matrices showed adequate degradation profiles as well as good swelling capacity, facilitating the penetration of the absorption medium into the porous structure, and consequently the drug diffusion through the gel network. The kinetic patterns recorded an initial fast drug release that reduces the inflammation and pain associated to a burn wound, followed by a progressive and sustained release securing the protective anti-inflammatory and analgesic effect for a longer period of time. These physicochemical, biopharmaceutical and biological properties of the designed formulations indicate the possibility of their use in burn treatment [30].

Testing the designed formulations on animal model like Wistar rats is critically important and frequently used in preclinical in vivo studies for the evaluation of the pharmacologic effect and the advancement in burn injury therapy due to the reticence on testing directly on human subjects [24].

Thus, the aim of this study was to test the therapeutic potential in burn healing and identify any possible major side effect induced by the treatment with the designed biopolymeric spongious matrices from our previous researches on experimentally induced burns to Wistar rats.

\section{Materials and Methods}

Preparation of biopolymeric spongious matrices The biopolymeric spongious matrices were obtained as previously described [30]. Briefly, type I fibrillar collagen gel (COLL) was extracted from calf hide using the technology developed at The National Research \& Development Institute for Textiles and Leather, Division of Leather and Footwear Research Institute, Department of Collagen Research, Bucharest, Romania [1]. Carboxymethylcellulose ( $\mathrm{NaCMC}$ ) was supplied from Fluka, glutaraldehyde (GA) from Merck and mefenamic acid (MA) from MP Biomedicals. The collagen gel and $\mathrm{NaCMC}$ gel with a final concentration of $1 \%$, and of $2 \%$ respectively, were mixed in different ratios, as shown in Table I. For the drug-loaded hydrogels, the MA concentration was $0.5 \%$. All hydrogels were cross-linked with glutaraldehyde for 24 hours at $4^{\circ} \mathrm{C}$. 


\begin{tabular}{|l|c|c|c|c|c|c|c|c|}
\hline Hydrogels composition & CC1 & CC2 & CC3 & CC4 & CCM5 & CCM6 & CCM7 & CCM8 \\
\hline COLL (\%) & 100 & 85 & 70 & 55 & 100 & 85 & 70 & 55 \\
\hline NaCMC (\%) & - & 15 & 30 & 45 & - & 15 & 30 & 45 \\
\hline MA (\%) & - & - & - & - & 0.5 & 0.5 & 0.5 & 0.5 \\
\hline GA (\%) & \multicolumn{7}{|c|}{0.0025} \\
\hline
\end{tabular}

The spongious matrices were than obtained by lyophilization (Delta 2-24 LSC Martin Christ lyophilizer) of corresponding hydrogels and coded as CC1 - CC4 (samples with no-anti-inflammatory drug) and CCM5 CCM8 (samples loaded with mefenamic acid).

Animal model of experimentally induced burn wound The experiment was performed on 50 Wistar rats weighing $180 \pm 10 \mathrm{~g}$ purchased from the Animal Biobase of the "Carol Davila" University of Medicine and Pharmacy, Bucharest, Romania.

All animals used in the study were kept in standard laboratory conditions, were fed twice a day and received water ad libitum. The experiment was performed in compliance with the European Communities Council Directive 2010/63/UE and Law No. 43 of the Romanian Parliament from 11 April 2014.

The animals were distributed in 9 groups of 5 individuals each as it follows: Group 1 - Control (not-treated), Group 2 - CC1, Group 3 - CC2, Group 4 - CC3,
Group 5 - CC4, Group 6 - CCM5, Group 7 - CCM6, Group 8-CCM7, Group 9-CCM8.

The animals were anesthetized with ether ethylic and the hair was removed from the dorsal area. The experimental wound was induced using a special metallic device of $1 \mathrm{~cm}$ diameter. The device was heated in boiling physiological serum and applied on the shaved dorsal area for 15 seconds. The severe burns measuring $1 \mathrm{~cm}$ diameter were sterilized and the biopolymeric spongious matrices were applied and fixed with a silk plaster. A control group was used in this study and the wounds were covered with sterile cotton dressing usually used for burns. The surface morphology of the wounds was recorded using a digital camera (Olympus SP-590UZ) in the absence of biopolymeric sponges and the wound diameter was measured for 20 days.

The re-epithelialization process was calculated according to the size profile of wound according to the following equation (eq. 1):

$$
\text { Re-epithelization } \%=\frac{(\text { Wound size at } t=0)-(\text { Wound size at } t)}{\text { Wound size at } t=0} \times 100
$$

where the wound size was an average measurement from the longest and shortest dimensions of the affected area [11, 32, 39].

Any aspects of inflammation or infection of the wounds, as well as any modification on the animal health status were also monitored. In the last day of the monitoring, the animals were ethyl-ether anesthetized and slaughtered. The blood was collected in $\mathrm{K}_{3}$ EDTA anticoagulant vacutainers for haematological tests to evaluate any possible general inflammation or anaemia as secondary effects induced by the treatment. A supplementary negative control group $(n=5)$ with no experimentally induced burn or treatment and monitored for 20 days was used for the comparison of the haematological data.

The blood analyses were performed using Abacus Junior haematological equipment. The specific reagents were purchased from Diatron Company.

Statistical analyses

Statistical analyses were performed using the GraphPad Prism 7 software. All data were expressed in mean and standard deviations (SD). Normal distribution was calculated using Kolmogorov-Smirnov test. The experimental data were evaluated using the student $t$-test and analyses of variance followed by Dunnett's multiple comparison test. The results were considered significant at $\mathrm{p}<0.05$, high significant at $\mathrm{p}<0.01$ and not significant at $\mathrm{p}>0.05$.

\section{Results and Discussion}

The experimentally induced burns to Wistar rats treated with new developed biopolymeric spongious matrices, previously in vitro tested [30] and with composition shown in Table I, were monitored for 20 days. The sponges were applied after inducing the burns and the healing process was compared to the control group which was classically treated with sterile cotton pad. The wound was considered healed after the crust of the lesion fell off.

The wound diameter evolution after the treatment with biopolymeric spongious matrices is presented in Table II. The macroscopic aspect of the wounds evolution is presented in Figure 1. The wounds healing process is presented in Figure 2.

Initially, the wounds were characterized by a white eschar and the skin layers, epidermis and dermis, were affected. A hyperaemic area appeared in the periphery and during the next hours it extended to a fully hyperaemic lesion due to erythrocyte extravasation and the post-traumatic inflammation. This initial phase of the burn injury comprises several homeostatic processes which are activated like platelets aggregations, immune defence and blood clotting. The biopolymeric 
FARMACIA, 2018, Vol. 66, 5

sponges applied in the initial homeostasis phase of the burns decreased the local damage in the treated group by supplying a scaffold-like matrix for the migration of the cells belonging to the first line defence barrier like fibroblast, keratinocytes, leukocytes and endothelial cells and by promoting the secretion of growth factors [24].

The initial homeostatic phase is generally followed by an inflammatory phase for 1 - 3 days characterized by an increased level of pro-inflammatory cytokines which stimulates neutrophils migration and the transformation of the monocytes into activated macrophages. Strong inflammatory signals in the local affected area could interfere with remodelling tissue process delaying the skin regenerations and promoting the formation of thick scars by increasing the secretion of extracellular matrix [15]. Short term use of nonsteroidal anti-inflammatory drugs like MA applied in topical formulations proved to be efficient in generation of normal skin with minimal scarring $[11,27]$.

Table II

Wound diameter ( $\mathrm{mm}$ ) evolution after treatment with biopolymeric spongious matrices in experimentally induced burn to Wistar rats

\begin{tabular}{|c|c|c|c|c|c|c|c|c|c|c|}
\hline Day & $\begin{array}{c}\text { Control } \\
\text { Mean } \pm \text { SD }\end{array}$ & $\begin{array}{c}\text { CC1 } \\
\text { Mean } \pm \text { SD }\end{array}$ & $\begin{array}{c}\text { CC2 } \\
\text { Mean } \pm \text { SD }\end{array}$ & $\begin{array}{c}\text { CC3 } \\
\text { Mean } \pm \text { SD }\end{array}$ & $\begin{array}{c}\text { CC4 } \\
\text { Mean } \pm \mathrm{SD}\end{array}$ & $\begin{array}{c}\text { CCM5 } \\
\text { Mean } \pm \text { SD }\end{array}$ & $\begin{array}{c}\text { CCM6 } \\
\text { Mean } \pm \text { SD }\end{array}$ & $\begin{array}{c}\text { CCM7 } \\
\text { Mean } \pm \text { SD }\end{array}$ & $\begin{array}{c}\text { CCM8 } \\
\text { Mean } \pm \text { SD }\end{array}$ & $\begin{array}{c}\text { ANOVA } \\
\text { p }\end{array}$ \\
\hline 1 & $10 \pm 0.0$ & $10 \pm 0.0$ & $10 \pm 0.0$ & $10 \pm 0.0$ & $10 \pm 0.0$ & $10 \pm 0.0$ & $10 \pm 0.0$ & $10 \pm 0.0$ & $10 \pm 0.0$ & - \\
\hline 3 & $11 \pm 0.55$ & $10 \pm 0.45$ & $10 \pm 0.45$ & $10 \pm 0.45$ & $10 \pm 0.45$ & $10 \pm 0.45$ & $10 \pm 0.45$ & $10 \pm 0.45$ & $10 \pm 0.0$ & 0.7331 \\
\hline 5 & $9.8 \pm 0.45$ & $8.8 \pm 0.84$ & $9.6 \pm 0.55$ & $9.4 \pm 0.55$ & $8.8 \pm 0.84$ & $8.6^{*} \pm 0.55$ & $7.6^{* * *} \pm 0.55$ & $8.6^{*} \pm 0.55$ & $8.4^{* * *} \pm 0.55$ & $<0.0001$ \\
\hline 7 & $9.2 \pm 0.45$ & $7.4^{* *} \pm 0.55$ & $7.4^{* *} \pm 0.55$ & $7.4^{* *} \pm 0.55$ & $6.8^{* *} \pm 0.45$ & $7.6^{* *} \pm 0.55$ & $7.4^{* *} \pm 0.55$ & $6.6^{* *} \pm 0.89$ & $6.0^{* *} \pm 0.71$ & $<0.0001$ \\
\hline 10 & $8.4 \pm 0.89$ & $7.2^{*} \pm 0.45$ & $6.4^{* *} \pm 0.55$ & $6.8^{* *} \pm 0.45$ & $6.0^{* *} \pm 0.71$ & $7.0^{*} \pm 0.0$ & $6.4^{* *} \pm 0.55$ & $6.2^{* *} \pm 0.84$ & $5.6^{* *} \pm 0.89$ & $<0.0001$ \\
\hline 12 & $7 \pm 0.5$ & $6 \pm 0.8$ & $6 \pm 2$ & $6 \pm 0.7$ & $5 \pm 0.5$ & $6 \pm 0.8$ & $6 \pm 1$ & $5 \pm 2$ & $4^{* *} \pm 3$ & 0.0079 \\
\hline 14 & $5.8 \pm 0.45$ & $5.4 \pm 0.55$ & $4.2 \pm 2.4$ & $5.0 \pm 0.71$ & $3.6 \pm 2.5$ & $5.0 \pm 1.2$ & $4.4 \pm 0.55$ & $3.8 \pm 1.6$ & $1.6^{* *} \pm 2.6$ & 0.0135 \\
\hline 17 & $4.2 \pm 2.5$ & $4.0 \pm 1.2$ & $3.6 \pm 2.1$ & $3.2 \pm 1.5$ & $3.0 \pm 2.7$ & $3.2 \pm 2.0$ & $3.2 \pm 2.2$ & $2.8 \pm 2.6$ & $1.0 \pm 2.2$ & 0.5236 \\
\hline 20 & $3 \pm 2.7$ & $2.2 \pm 2.5$ & $1 \pm 1.4$ & $1 \pm 1.4$ & $1.6 \pm 2.2$ & $1.2 \pm 1.6$ & $0.4 \pm 0.89$ & $1.4 \pm 1.9$ & $0 \pm 0$ & 0.3129 \\
\hline
\end{tabular}

Statistical significance calculated using Dunnett's Multiple Comparison Test (vs. Control): ${ }^{*}(\mathrm{p}<0.05),{ }^{* * *}(\mathrm{p}<0.01),{ }^{* * *}(\mathrm{p}<0.001)$.

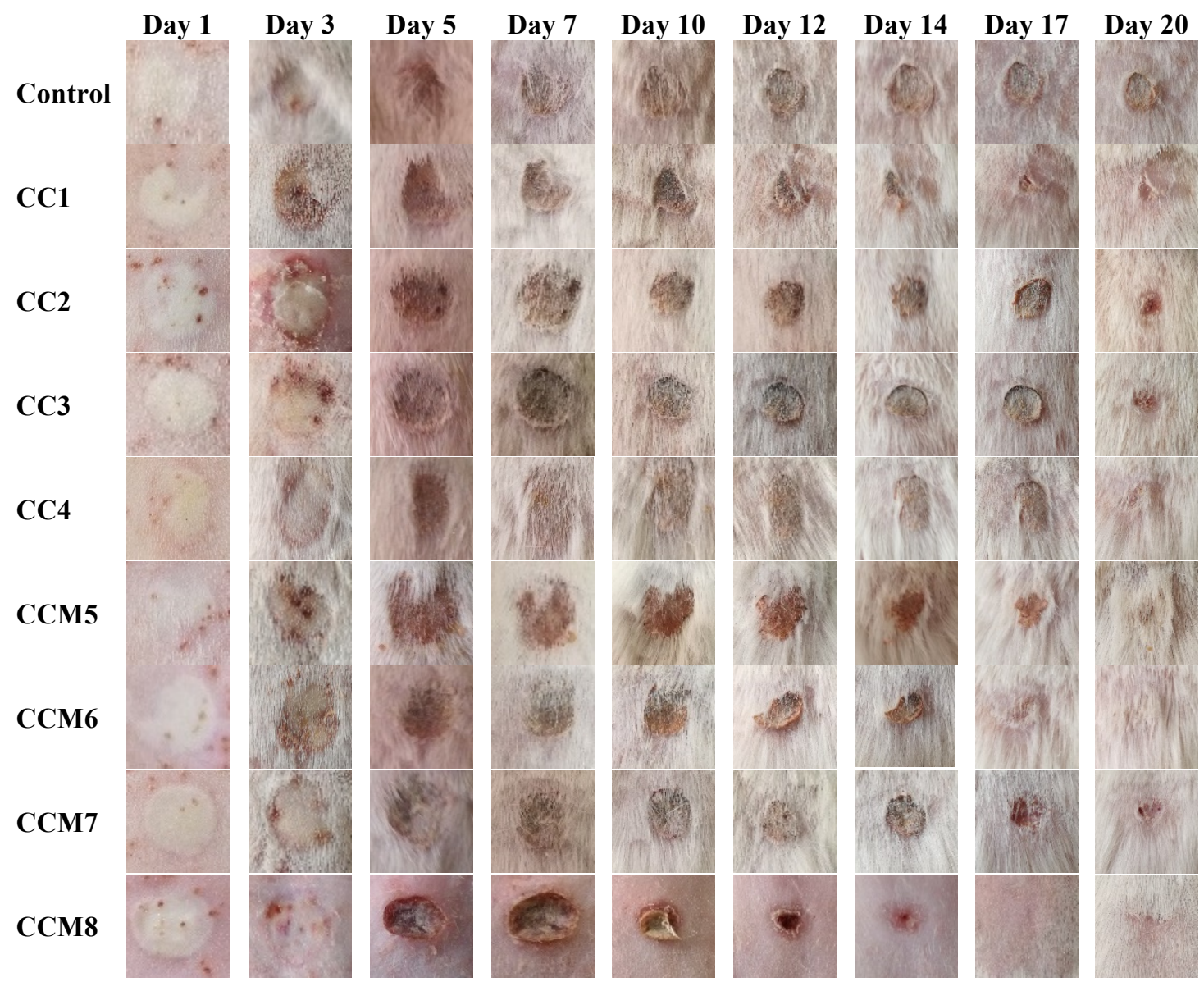

Figure 1.

The evolution of the wound healing after the treatment with biopolymeric spongious matrices 


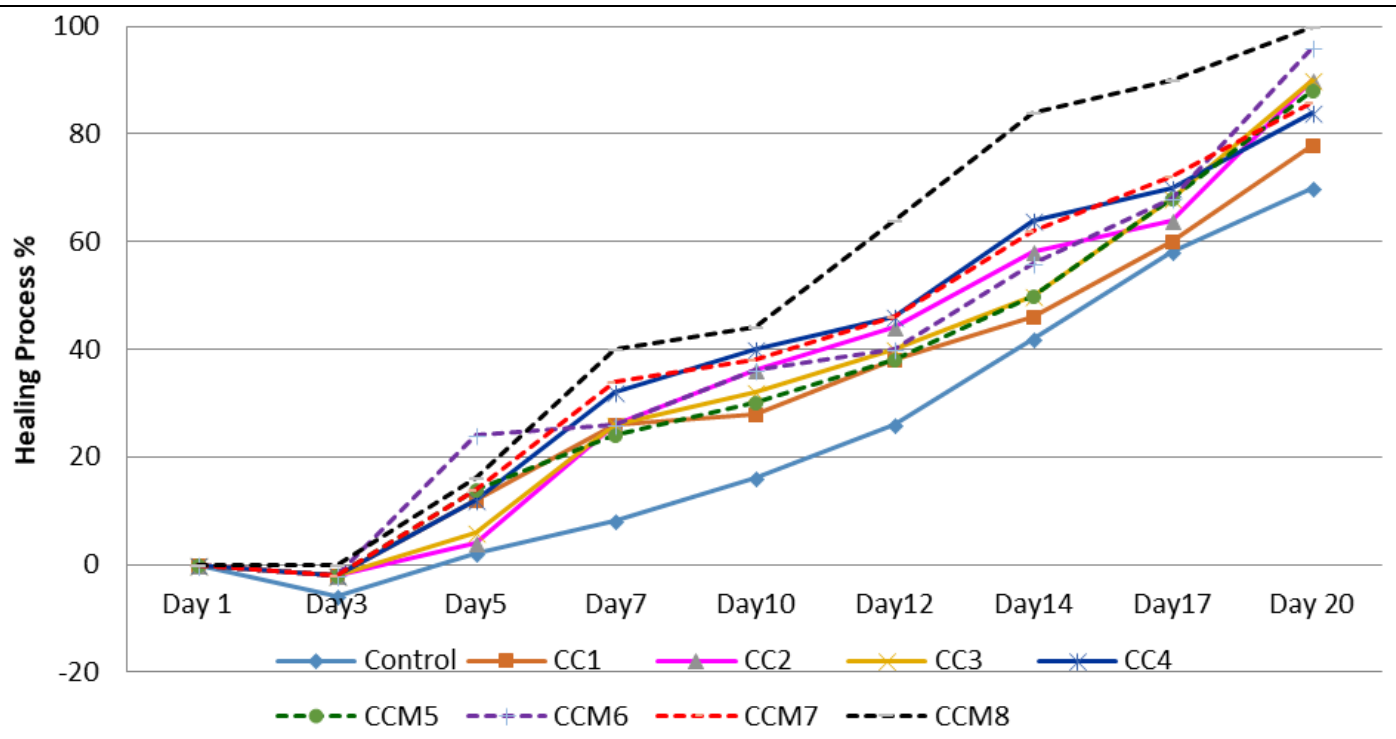

Figure 2.

The wound healing process (\%) after the treatment with biopolymeric spongious matrices

After 3 days, a slight inflammatory post traumatic effect was noticed in case of the control group reflected by an increased wound diameter in comparison with all treated groups (Table II, Figure 2). Following the next days, the re-epithelization process was accelerated in treated groups and was associated with decreasing wound diameters in these groups comparing to control. In day 5 , the healing process was significant $(\mathrm{p}<0.001)$ in case of the CCM6 followed by CCM8 with a decrease of wound diameter by $34 \%$ and $26 \%$ comparing to control group (Figure 2, Table II). In all cases, the addition of the anti-inflammatory drug in the biopolymeric spongious matrices formulations (CCM groups) improved the wound healing in comparison with the respective sponges control groups (CC) after 5 days (CC1 vs. CCM5, CC2 vs. CCM6, CC3 vs. CCM7, CC4 vs. CCM8).

The treatment with wound dressings containing or not the mefenamic acid demonstrated a significant $(p<0.05)$ decrease of the lesion diameters in days 7 and 10 compared to control group. Moreover, the biopolymeric spongious matrices without anti-inflammatory agent also proved to be more efficient in comparison with the control group due to the known capacity of healing and regeneration of both collagen and $\mathrm{NaCMC}$. The epithelial tissue remodelling phase associated with the complete healing process in all animals of the group was noticed after 17 days for the treatment with CCM8 sponge (Figure 1, Table II, Figure 2) followed by CCM6 group after 20 days. In case of the other treated groups $(\mathrm{CC} 1, \mathrm{CC} 2, \mathrm{CC} 3, \mathrm{CC} 4$, $\mathrm{CCM} 5, \mathrm{CCM} 7)$, the results were similar $(\mathrm{p}>0.05)$ when comparing to each other with a slight delay of healing in case of $\mathrm{CC} 1$ group. The less visible scars generally correlated with an optimal tissue remodelling process were noticed in case of CCM8 and CCM6 treatment groups. The control group showed the slowest and uncompleted healing process sustained by the presence of the thick layer scars in all animal injuries (Figure 1).

The haematological analysis of some blood parameters after the treatment with biopolymeric spongious matrices was performed for determining possible systemic effects of the treatment with these new developed wound dressings (Tables III and IV). Post traumatic secondary effects commonly developed after burn injuries are secondary infections or anaemia.

The classical haematological parameters usually used to detect the presence of anaemia are red blood cell (RBC), haemoglobin (HGB), haematocrit (HCT), mean cell volume $(\mathrm{MCV})$, mean cell haemoglobin $(\mathrm{MCH})$, mean cell haemoglobin concentration (MCHC), red blood cell distribution width (RDW).

No significant variation of the haematological parameters correlated with anaemia or other erythrocyte pathologies were observed after the experimentally induced burns treatment with biopolymeric spongious matrices compared to negative control.

The leucocyte formula (white blood cells count WBC, lymphocytes \% - Ly, monocytes \% - Mi, granulocytes $\%-\mathrm{Gr}$ ) is an usual blood analysis for detecting the possible secondary infection or inflammation induced by the treatment. The wound dressings containing or not the mefenamic acid induced no significant changes within the leucocyte formula. 
Table III

The variation of the red blood cell level, haemoglobin and erythrocyte indices after experimentally induced burns to Wistar rats and treated with biopolymeric spongious matrices

\begin{tabular}{|l|c|c|c|c|c|c|c|}
\hline & $\begin{array}{c}\text { RBC (x 10 } / \mu \mathbf{~ L )} \\
\text { Mean } \pm \text { SD }\end{array}$ & $\begin{array}{c}\text { HGB (g/dL) } \\
\text { Mean } \pm \text { SD }\end{array}$ & $\begin{array}{c}\text { HCT (\%) } \\
\text { Mean } \pm \text { SD }\end{array}$ & $\begin{array}{c}\text { MCV (fl) } \\
\text { Mean } \pm \text { SD }\end{array}$ & $\begin{array}{c}\text { MCH (pg/cell) } \\
\text { Mean } \pm \text { SD }\end{array}$ & $\begin{array}{c}\text { MCHC (g/dL) } \\
\text { Mean } \pm \text { SD }\end{array}$ & $\begin{array}{c}\text { RDW } \\
\text { Mean } \pm \text { SD }\end{array}$ \\
\hline Control & $8.22 \pm 0.4$ & $15.0 \pm 0.2$ & $41.65 \pm 1.31$ & $50.75 \pm 1.89$ & $18.28 \pm 1.17$ & $35.98 \pm 1.35$ & $18.25 \pm 0.47$ \\
\hline CC1 & $7.45 \pm 0.25$ & $14.57 \pm 0.59$ & $37.94 \pm 0.67$ & $51.00 \pm 1.73$ & $19.60 \pm 0.53$ & $38.73 \pm 1.42$ & $18.00 \pm 0.40$ \\
\hline CC2 & $8.19 \pm 0.29$ & $15.80 \pm 0.90$ & $39.00 \pm 2.07$ & $47.67 \pm 0.58$ & $19.23 \pm 0.47$ & $40.47 \pm 0.32$ & $18.00 \pm 0.69$ \\
\hline CC3 & $8.17 \pm 0.12$ & $15.70 \pm 0.30$ & $38.52 \pm 0.88$ & $47.00 \pm 1.00$ & $19.13 \pm 0.42$ & $40.57 \pm 0.50$ & $18.50 \pm 1.37$ \\
\hline CC4 & $8.34 \pm 0.21$ & $16.10 \pm 0.17$ & $39.33 \pm 0.38$ & $47.00 \pm 1.00$ & $19.30 \pm 0.26$ & $40.87 \pm 0.21$ & $17.77 \pm 0.70$ \\
\hline CCM5 & $7.69 \pm 0.12$ & $14.85 \pm 0.47$ & $36.93 \pm 0.98$ & $48.75 \pm 1.26$ & $19.65 \pm 0.21$ & $40.23 \pm 0.80$ & $18.03 \pm 0.47$ \\
\hline CCM6 & $7.66 \pm 0.34$ & $14.80 \pm 0.54$ & $36.72 \pm 1.03$ & $48.00 \pm 0.82$ & $19.30 \pm 0.42$ & $31.25 \pm 1.85$ & $18.85 \pm 0.50$ \\
\hline CCM7 & $8.07 \pm 0.15$ & $15.50 \pm 0.14$ & $37.11 \pm 0.33$ & $46.00 \pm 0.82$ & $19.23 \pm 0.26$ & $41.87 \pm 0.56$ & $18.83 \pm 0.84$ \\
\hline CCM8 & $8.43 \pm 0.52$ & $16.40 \pm 0.01$ & $38.36 \pm 2.74$ & $45.33 \pm 0.58$ & $18.80 \pm 0.44$ & $41.37 \pm 1.12$ & $18.20 \pm 0.62$ \\
\hline $\begin{array}{l}\text { Negative } \\
\text { Control }\end{array}$ & $8.40 \pm 0.36$ & $14.93 \pm 0.3$ & $42.22 \pm 0.78$ & $50.33 \pm 2.08$ & $17.77 \pm 0.71$ & $35.30 \pm 0.10$ & $18.13 \pm 0.50$ \\
\hline
\end{tabular}

$\mathrm{RBC}=$ red blood cell, $\mathrm{HGB}=$ haemoglobin, $\mathrm{HCT}=$ haematocrit, $\mathrm{MCV}=$ mean cell volume, $\mathrm{MCH}=$ mean cell haemoglobin, $\mathrm{MCHC}=$ mean cell haemoglobin concentration, RDW $=$ red blood cell distribution width, $\mathrm{SD}=$ standard deviation

Table IV

The variation of the white blood cell count after experimentally induced burns to Wistar rats and treated with

biopolymeric spongious matrices

\begin{tabular}{|l|c|c|c|c|}
\hline Group & $\begin{array}{c}\text { WBC }(\mathbf{x ~ 1 0} / \boldsymbol{\mu L}) \\
\text { Mean } \pm \text { SD }\end{array}$ & $\begin{array}{c}\mathbf{L y \%} \\
\text { Mean } \pm \text { SD }\end{array}$ & $\begin{array}{c}\text { Mi\% } \\
\text { Mean } \pm \text { SD }\end{array}$ & $\begin{array}{c}\text { Gr\% } \\
\text { Mean } \pm \text { SD }\end{array}$ \\
\hline Control & $4.26 \pm 1.06$ & $52.50 \pm 8.46$ & $14.55 \pm 3.16$ & $32.95 \pm 8.08$ \\
\hline CC1 & $4.18 \pm 1.55$ & $33.63 \pm 2.19$ & $17.27 \pm 4.48$ & $49.10 \pm 14.62$ \\
\hline CC2 & $4.82 \pm 0.60$ & $43.20 \pm 8.51$ & $13.87 \pm 1.32$ & $42.93 \pm 7.20$ \\
\hline CC3 & $3.84 \pm 1.06$ & $46.93 \pm 3.50$ & $13.63 \pm 2.85$ & $39.43 \pm 1.93$ \\
\hline CC4 & $3.59 \pm 0.85$ & $45.27 \pm 3.04$ & $13.37 \pm 3.16$ & $41.37 \pm 1.77$ \\
\hline CCM5 & $4.46 \pm 1.80$ & $37.70 \pm 2.24$ & $12.93 \pm 2.56$ & $49.38 \pm 1.09$ \\
\hline CCM6 & $4.56 \pm 0.68$ & $45.25 \pm 3.04$ & $14.20 \pm 2.05$ & $40.55 \pm 2.82$ \\
\hline CCM7 & $4.09 \pm 0.70$ & $34.40 \pm 5.36$ & $23.70 \pm 2.24$ & $41.90 \pm 0.74$ \\
\hline CCM8 & $4.24 \pm 1.64$ & $44.87 \pm 4.03$ & $16.33 \pm 2.70$ & $38.80 \pm 6.42$ \\
\hline Negative Control & $4.41 \pm 1.25$ & $54.84 \pm 8.65$ & $15.03 \pm 3.67$ & $30.13 \pm 7.09$ \\
\hline
\end{tabular}

$\mathrm{WBC}=$ white blood cell, $\mathrm{Ly}=$ lymphocytes $\%, \mathrm{Mi}=$ monocytes $\%, \mathrm{Gr}=$ granulocytes $\%, \mathrm{SD}=$ standard deviation .

\section{Conclusions}

The designed biopolymeric spongious matrices increased the healing properties with no secondary systemic or topic effects compared to the classical treated control group. The presence of mefenamic acid accelerated the wound healing with a faster epithelial regeneration and a minimal scarring in comparison to the formulations containing no anti-inflammatory drug. The best results were obtained with CCM6 and CCM8 biopolymeric spongious matrices (mefenamic acid-loaded and with a ratio between collagen and sodium carboxymethylcellulose as follows: 85:15, and 55:45 respectively), sustaining our previously in vitro studies regarding their physicochemical, biopharmaceutical and biological properties.

The results are optimistic regarding the possible use of these new developed formulations in the therapy of moderate burns, with beneficial effects in the homeostatic and inflammatory phases and with long term consequences on the remodelling phase of the cicatrizing process.

\section{Acknowledgement}

This study was financially supported by UEFISCDI, PN-III-Experimental Demonstration Project, project number PED 160/03.01.2017, code PN-III-P2-2.1PED-2016-0813, Romania.

\section{References}

1. Albu MG, Collagen gels and matrices for biomedical applications. Lambert Academic Publishing, Saarbrücken, Germany, 2011; 23-24.

2. Alshehri SM, Park JB, Alsulays BB, Tiwari RV, Almutairy B, Alshetaili AS, Morott J, Kulkarni V, Majumdar S, Martin ST, Mishra S, Wang L, Repka MA, Mefenamic acid taste-masked oral disintegrating tablets with enhanced solubility via molecular interaction produced by hot melt extrusion technology. J Drug Deliv Sci Technol., 2015; 27: 18-27.

3. Basar AO, Castro S, Torres-Giner S, Lagaron JM, Turkoglu Sasmazel H, Novel poly(e-caprolactone)/ gelatin wound dressings prepared by emulsion electrospinning with controlled release capacity of Ketoprofen anti-inflammatory drug. Mater Sci Eng C Mater Biol Appl., 2017; 81: 459-468. 
FARMACIA, 2018, Vol. 66, 5

4. Boateng JS, Matthews KH, Auffret AD, Humphrey MJ, Stevens HN, Eccleston GM, In vitro drug release studies of polymeric freeze-dried wafers and solventcast films using paracetamol as a model soluble drug. Int J Pharm., 2009; 378(1-2): 66-72.

5. Capanema NSV, Mansur AAP, de Jesus AC, Carvalho SM, de Oliveira LC, Mansur HS, Superabsorbent crosslinked carboxymethyl cellulose-PEG hydrogels for potential wound dressing applications. Int J Biol Macromol., 2018; 106: 1218-1234.

6. Ehrl D, Heidekrueger PI, Ninkovic M, Broer PN, Effect of primary admission to burn centers on the outcomes of severely burned patients. Burns, 2018; 44(3): 524-530.

7. Fan L, Peng M, Zhou X, Wu H, Hu J, Xie W, Liu S, Modification of carboxymethyl cellulose grafted with collagen peptide and its antioxidant activity. Carbohydr Polym., 2014; 112: 32-38.

8. Fan X, Chen K, He X, Li N, Huang J, Tang K, Li Y, Wang $\mathrm{F}, \mathrm{Nano}-\mathrm{TiO}_{2} /$ collagen-chitosan porous scaffold for wound repairing. Int J Biol Macromol., 2016; 91: 15-22.

9. Ferreira H, Matamá T, Silva R, Silva C, Gomes AC, Cavaco-Paulo A, Functionalization of gauzes with liposomes entrapping an anti-inflammatory drug: A strategy to improve wound healing. React Funct., 2013; 73: 1328-1334.

10. Fierăscu RC, Dinu-Pîrvu CE, Fierăscu I, Țărmure V, Stanică N, Nicolae CA, Somoghi R, Trică B, Anuţa V, Inorganic/organic core-shell magnetic materials for removal of endocrine disrupting pharmaceuticals from water. Farmacia, 2018; 66(2): 316-322.

11. Ghica MV, Albu Kaya MG, Dinu-Pîrvu CE, Lupuleasa $\mathrm{D}$, Udeanu DI, Development, optimization and in vitro/ in vivo characterization of collagen-dextran spongious wound dressings loaded with flufenamic acid. Molecules, 2017; 22(9): E1552.

12. Ghica MV, Hîrjău M, Lupuleasa D, Dinu-Pîrvu CE, Flow and thixotropic parameters for rheological characterization of hydrogels. Molecules, 2016; 21(6): E786.

13. Gokce EH, Tuncay Tanrıverdi S, Eroglu I, Tsapis N, Gokce G, Tekmen I, Fattal E, Ozer O, Wound healing effects of collagen-laminin dermal matrix impregnated with resveratrol loaded hyaluronic acidDPPC microparticles in diabetic rats. Eur J Pharm Biopharm., 2017; 119: 17-27.

14. Guo R, Xu S, Ma L, Huang A, Gao C, The healing of full-thickness burns treated by using plasmid DNA encoding VEGF-165 activated collagen-chitosan dermal equivalents. Biomaterials, 2011; 32(4): 1019-1031.

15. Guo S, DiPietro LA, Factors affecting wound healing. J Dent Res., 2010; 89(3): 219-229.

16. Haifei S, Xingang W, Shoucheng W, Zhengwei M, Chuangang Y, The effect of collagen-chitosan porous scaffold thickness on dermal regeneration in a onestage grafting procedure. J Mech Behav Biomed Mater., 2014; 29: 114-125.

17. Jhawat V, Gupta S, Saini V, Formulation and evaluation of novel controlled release of topical pluronic lecithin organogel of mefenamic acid. Drug Deliv., 2016; 23(9): 3573-3581.
18. Khullar R, Kumar D, Seth N, Saini S, Formulation and evaluation of mefenamic acid emulgel for topical delivery. Saudi Pharm J., 2012; 20(1): 63-67.

19. Lungu A, Titorencu I, Albu MG, Florea NM, Vasile E, Iovu H, Jinga V, Simionescu M, The effect of BMP-4 loaded in 3D collagen-hyaluronic acid scaffolds on biocompatibility assessed with MG 63 osteoblastlike cells. Dig J Nanomater Biostruct., 2011; 6(4): 1897-1908.

20. Mahmoud AA, Salama AH, Norfloxacin-loaded collagen/chitosan scaffolds for skin reconstruction: Preparation, evaluation and in-vivo wound healing assessment. Eur J Pharm Sci., 2016; 83: 155-165.

21. Maver T, Gradišnik L, Kurečič M, Hribernik S, Smrke DM, Maver U, Kleinschek KS, Layering of different materials to achieve optimal conditions for treatment of painful wounds. Int J Pharm., 2017; 529(1-2): 576-588.

22. Mederle N, Marin Ș, Marin MM, Dănilă E, Mederle O, Albu Kaya MG, Ghica MV, Innovative biomaterials based on collagen-hydroxyapatite and doxycycline for bone regeneration. Adv Mater Sci Eng., 2016; article ID 3452171: 1-5.

23. Mirastschijski U, Sander JT, Weyand B, Rennekampff HO, Rehabilitation of burn patients: an underestimated socio-economic burden. Burns, 2013; 39(2): 262-268.

24. Mofazzal Jahromi MA, Sahandi Zangabad P, Moosavi Basri SM, Sahandi Zangabad K, Ghamarypour A, Aref AR, Karimi M, Hamblin MR, Nanomedicine and advanced technologies for burns: Preventing infection and facilitating wound healing. Adv Drug Deliv Rev., 2018; 123: 33-64.

25. Montalbano G, Toumpaniari S, Popov A, Duan P, Chen J, Dalgarno K, Scott III WE, Ferreira AM, Synthesis of bioinspired collagen/alginate/fibrin based hydrogels for soft tissue engineering. Mater Sci Eng C Mater Biol Appl., 2018; 91: 236-246.

26. Moreira RB, Teixeira JA, Furuyama-Lima AM, de Souza NC, Siqueira AB, Preparation, characterization and evaluation of drug-delivery systems: Pectin and mefenamic acid films. Thermochim Acta, 2014; 590: 100-106.

27. Morgado PI, Miguel SP, Correia IJ, Aguiar-Ricardo A, Ibuprofen loaded PVA/chitosan membranes: A highly efficient strategy towards an improved skin wound healing. Carbohydr Polym., 2017; 159: 136-145.

28. Muţ AM, Vlaia L, Coneac G, Olariu I, Vlaia V, Stănciulescu C, Mitu MA, Szabadai Z, Lupuliasa D, Chitosan/HPMC-based hydrogels containing essential oils for topical delivery of fluconazole: preliminary studies. Farmacia, 2018; 66(2): 248-256.

29. Ng SF, Jumaat N, Carboxymethyl cellulose wafers containing antimicrobials: a modern drug delivery system for wound infections. Eur J Pharm Sci., 2014; 51: 173-179.

30. Nitipir C, Marin Ș, Marin MM, Albu Kaya MG, Ghica MV, Mederle N, Hybrid collagen-NaCMC matrices loaded with mefenamic acid for wound healing. Rev Chim. (Bucharest), 2017; 68(11): 2605-2609.

31. Ragothaman M, Palanisamy T, Kalirajan C, Collagenpoly(dialdehyde) guar gum based porous $3 \mathrm{D}$ scaffolds immobilized with growth factor for tissue engineering applications. Carbohydr Polym., 2014; 114: 399-406. 
32. Ramli NA, Wong TW, Sodium carboxymethylcellulose scaffolds and their physicochemical effects on partial thickness wound healing. Int $J$ Pharm., 2011; 403(1-2): 73-82.

33. Sriamornsak P, Limmatvapirat $S$, Piriyaprasarth $S$, Mansukmanee P, Huang Z, A new self-emulsifying formulation of mefenamic acid with enhanced drug dissolution. Asian J Pharm Sci., 2015; 10(2): 121-127.

34. Suksaeree J, Piamsap K, Paktham S, Kenprom T, Monton C, Pichayakorn W, Formulation development of matrix type transdermal patches containing mefenamic acid: physicochemical characterization and in vitro release evaluation. Monatsh Chem., 2017; 148(7): 1215-1222.

35. Tort S, Acartürk F, Beşikci A, Evaluation of threelayered doxycycline-collagen loaded nanofiber wound dressing. Int J Pharm., 2017; 529(1-2): 642-653.

36. Wang Y, Beekman J, Hew J, Jackson S, Issler-Fisher AC, Parungao R, Lajevardi SS, Li Z, Maitz PKM, Burn injury: Challenges and advances in burn wound healing, infection, pain and scarring. Adv Drug Deliv Rev., 2018; 123: 3-17.
37. Wong TW, Ramli NA, Carboxymethylcellulose film for bacterial wound infection control and healing. Carbohydr Polym., 2014; 112: 367-375.

38. Wu YJ, Chen T, Chen IF, Kuo SM, Chuang CW, Developing highly porous collagen scaffolds by using alginate microsphere porogens for stem cell cultures. Mater Lett., 2018; 223: 120-123.

39. Xie H, Chen X, Shen X, He Y, Chen W, Luo Q, Ge W, Yuan W, Tang X, Hou D, Jiang D, Wang Q, Liu Y, Liu Q, Li K, Preparation of chitosan-collagen-alginate composite dressing and its promoting effects on wound healing. Int J Biol Macromol., 2018; 107(Pt A): 93-104.

40. Xue M, Zhao R, Lin H, Jackson C, Delivery systems of current biologicals for the treatment of chronic cutaneous wounds and severe burns. Adv Drug Deliv Rev., 2018; [Epub ahead of print].

41. Zhang M, Ding C, Yang J, Lin S, Chen L, Huang L, Study of interaction between water-soluble collagen and carboxymethyl cellulose in neutral aqueous solution. Carbohydr Polym., 2016; 137: 410-417. 